\title{
Ультразвуковий скринінг гострого апендициту у вагітних
}

\begin{abstract}
Мета роботи: профілактика передчасних родорозрішень шляхом удосконалення методів діагностики з використанням ультразвукового скринінгу та вибору хірургічної тактики у вагітних з гострою хірургічною патологією залежно від результатів скринінгу. Матеріали і методи. Проведено ретроспективний огляд історій хвороби та амбулаторних карт пацієнтів із підозрою на гостру хірургічну патологію органів черевної порожнини у КНП «Київська міська клінічна лікарня № 1 » 2016 року до 2021 р. Результати досліджень та їх обговорення. Всім вагітним проводили необхідні клініко-лабораторні та інструментальні методи дослідження відповідно до оновлених клінічних протоколів надання хірургічної допомоги вагітним. В окремих випадках було виконано магнітно-резонансну діагностику та комп’ютерну томографію для деталізації поширення патологічного процесу та відповідно вибору методу операційного втручання.

Особливості клінічної картини ГА зумовлені анатомо-фізіологічними особливостями вагітних жінок. Із збільшенням терміну гестації ми спостерігали більш виражену зміну клінічних проявів ГА з більш стрімким перебігом захворювання. Певне значення в діагностиці ГА у вагітних мають показники лабораторних досліджень. Лейкоцитоз, нейтрофільний зсув лейкоцитарної формули вліво, лімфоцитопенія свідчать на користь апендициту.

Токолітичну терапію використовували як при передопераційній підготовці, так і інтраопераційно, що суттєво впливає на профілактику передчасних пологів та ускладнень вагітності.

Післяопераційних ускладнень у даній популяції не спостерігали.

Деталізація діагнозу у вагітних із гострою хірургічною патологією за допомогою новітніх методів діагностики дала можливість вибору тактики та методології хірургічного лікування. Ультразвукове сканування є високочутливим та специфічним у 71 \% вагітних при гострому апендициті.

Впровадження мініінвазивних методів дало можливість скоротити кількість перебування вагітних у стаціонарі та використання їх в III триместрі вагітності (8 \% від загальної кількості оперованих).
\end{abstract}

Ключові слова: гострий апендицит; ультразвуковий скринінг; вагітні; лапароскопія; аналіз методів.

Постановка проблеми і аналіз останніх досліджень та публікацій. Гострий апендицит (ГА) - гостре хірургічне захворювання, що найчастіше зустрічається у вагітних жінок та несвоєчасна діагностика якого може становити загрозу життю матері та плода. Захворюваність вагітних на гострий апендицит не вища, ніж така в загальній популяції, і складає 0,03-5,20 \% випадків. За даними останніх гострий апендицит найчастіше виникає в I (19-32 \%) та II (44-66 \%) триместрах вагітності, дещо рідше в III триместрі (15-16 \%) [1]. Деструктивні форми апендициту частіше виникають в III триместрі, перинатальні наслідки бувають гіршими у II триместрі вагітності. Під час вагітності діагностика гострого апендициту та інших захворювань, що супроводжуються симптомами “гострого живота”, більш складна, ніж у невагітних. За даними досліджень Н. М. Подзолкової та В. С. Семенової, у 2/3 хворих на апендицит, які звернулись в жіночу консультацію, були направлені в пологовий будинок із діагнозом загрози передчасного переривання вагітності $[1,2]$. У цілому, на догоспітальному етапі правильний діагноз ГА був встановлений лише у 42,9 \% вагітних. Таким чином, більш ніж у 50 \% спостережень апендициту у вагітних припускалась діагностична помил- ка, внаслідок якої траплялась непрофільна госпіталізація хворих та затримка операції. В зв'язку із складностями клінічної діагностики ГА в кожної третьої вагітної апендектомію виконували більш ніж через 24 години від початку захворювання $[3,4]$. Діагностика гострого апендициту у вагітних залишається дискутабельною темою в невідкладній хірургії $[4,5]$, а саме, який комплекс діагностики $є$ вичерпним для показань хірургічного лікування, який визначає терміни передопераційної підготовки та вибору методу операційного лікування. За даними ВООЗ гостра хірургічна патологія органів черевної порожнини, яка вимагає хірургічного втручання у вагітних, складає від 12,5 до 16,4 \% від загальної кількості. Актуальним у даній популяції є профілактика передчасних родорозрішень та інших ускладнень під час вагітності [6]. Особливої актуальності набуває вибір хірургічного втручання у вагітних залежно від триместру $[7,8]$.

Мета роботи: профілактика передчасних родорозрішень шляхом удосконалення методів діагностики із використанням ультразвукового скринінгу та вибору хірургічної тактики у вагітних із гострою хірургічною патологією залежно від результатів скринінгу. 


\section{З ДОСВІДУ РОБОТИ}

Матеріали і методи. У КНП «Київська міська клінічна лікарня № 1» 32016 року до 2021 р. включно було госпіталізовано 1001 вагітну з підозрою на гостру хірургічну патологію органів черевної порожнини. 3 них 124 жінки (12,4 \%) потребували хірургічного втручання. 877 вагітних (87,6 \%), які не потребували операційного лікування, звертались 3: синдром подразненого кишечника - 547 жінки (62,4 \%), ниркова коліка - 163 жінки (18,6 \%), загострення холецистопанкреатиту - 82 жінки (9,3 \%), тромбофлебіти/флеботромбози - 28 жінки (3,2 \%), неускладнені геморої - 36 жінок (4,1%), з копростазом - 12 жінок (1,3 \%) та 9 жінок з вправимими килами (1,1%). Жінкам, які потребували хірургічне лікування, виконували: апендектомію - 82 жінки (66 \%), з них у першому триместрі - 45 жінок (55 \%) та у другому триместрі - 15 жінок (18,2 \%), лапароскопічна холецистектомія 17 осіб - (13,7 \%), плікація поверхневої стегнової вени та операція Троянова - Тренделенбурга - 11 жінок (8,9 \%), герніосічення - 6 жінок (5 \%), усунення кишкової непрохідності - 4 жінки (3,2 \%), контактна літотрипсія - 2 жінки (1,6 \%), гемороїдектомія при кровотечі з гемораїдального вузла - 1 жінка (0,8 \%), кровотеча з виразки шлунка - 1 жінка (0,8 \%).

Вищезазначена нозологія була диференційована з використанням усіх інструментальних методів, якими оснащена наша клініка, а саме: УЗД, МРТ, KT, цифрова рентгенографія. 382 вагітних, яким була виконана апендектомія, у 58 вагітних під час ультразвукового обстеження було визначено розташування апендикса та форму запального процесу, що збігалося з інтраопераційною картиною. У 24 вагітних використано МРТ діагностику через атиповий клінічний перебіг, що збігалося з розташуванням апендикса в заочеревинному просторі. Це спонукало до вибору методу та доступу з метою запобігання технічних незручностей та профілактики післяопераційних ускладнень. У цій групі хворих апендектомію закінчували дренуванням ложа запального процесу, незалежно від триместру.

Результати досліджень та їх обговорення. Всім вагітним проводились необхідні клініко-лабораторні та інструментальні методи дослідження відповідно до оновлених клінічних протоколів надання хірургічної допомоги вагітним. В окремих випадках було виконано магнітно-резонансну діагностику та комп’ютерну томографію для деталізації поширення патологічного процесу та відповідно вибору методу операційного втручання.

Враховуючи вищезазначену структуру хірургічної нозології у вагітних, що 50 \% хірургічних втручань із використанням мініінвазивних методів лікування припадає на I триместр вагітності. У другому триместрі у 24 \% випадків використовували також мініінвазивні технології при лікуванні гострого апендициту та гострого холециститу. В III триместрі мініінвазивні технології використовували в 8 \%.

Особливості клінічної картини ГА зумовлені анатомо-фізіолоічними особливостями вагітних жінок. Наші дані корелюють 3 даними інших дослідників. Більшість дослідників вважає, що клінічна картина ГА залежить від терміну вагітності та вираження патологічного процесу в апендиксі. Сєров В. Н. та співавт. зазначають, що клінічні прояви апендициту не відрізняються від симптомів даного захворювання у невагітних лише в I та першій половині II триместра. Але треба наголосити, що такі симптоми, як гіпертермія, нудота та блювота, на початку вагітності можуть бути зумовлені токсикозом першої половини вагітності. Болі в животі є типовими для загрози передчасного переривання вагітності або позаматкової вагітності. Із збільшенням терміну гестації ми спостерігали більш виражену зміну клінічних проявів ГА з більш стрімким перебігом захворювання. В III триместрі діагностика даного захворювання стає найбільш складною. Від початку 20-21 тижня вагітності сліпа кишка та апендикс зміщуються вгору та латерально, спричиняючи його перегини, погіршення мікроциркуляції, застій його вмісту та функціональну перебудову лімфоїдної тканини. Черевна стінка в цей період дещо ригідна через її перерозтягнення вагітною маткою. Певне значення в діагностиці ГА у вагітних мають показники лабораторних досліджень. Лейкоцитоз, нейтрофільний зсув лейкоцитарної формули вліво, лімфоцитопенія свідчать на користь апендициту. Разом із тим, даних лабораторного дослідження при підозрі на ГА у вагітних часто недостатньо для прийняття рішення про хірургічне лікування.

Діагностична цінність загального аналізу крові збільшується при зіставленні лейкоцитозу та ЧСС. ЧСС вище 100 уд. за 1 хв у поєднанні з лейкоцитозом вище 12-14 ×10 \%/л навіть на тлі нормальної температури тіла може свідчити про тяжкий деструктивний апендицит. Ступінь лейкоцитозу свідчить про глибину морфологічних змін в апендиксі. Однак ця залежність не завжди виявляється. У випадку сумнівної клініки або атипового перебігу ГА поруч із динамічним клінічним та лабораторним наглядом ми застосовували такий прийом із метою диференційної діагностики ГА та загрози переривання вагітності. Внутрішньовенне введення Sol. $\mathrm{NaCl}$ 0,9 \% - 200,0 ml + Sol. MgSO $425 \%$ - 30,0ml та в/м введення Sol. Papaverini 2 \% - 2,0 ml. Збереження больового синдрому в правій здухвинній ділянці після проведеної терапії свідчило на користь ГА, що підтверджувалось інтраопераційними знахідками. 


\section{З ДОСВІДУ РОБОТИ}

Токолітичну терапію використовували як при передопераційній підготовці, так і інтраопераційно, що суттєво впливає на профілактику передчасних пологів та ускладнень вагітності.

Післяопераційних ускладнень у даній популяції не спостерігали.

Висновки. 1. Ультразвукове сканування $є$ високочутливим та специфічним у 71 \% вагітних при гострому апендициті.

2. Деталізація діагнозу у вагітних із гострою хірургічною патологією за допомогою новітніх методів діагностики дала можливість вибору тактики та методології хірургічного лікування.

3. Обов’язковий УЗ-моніторинг у післяопераційному періоді, оскільки післяопераційний біль може “маскувати” акушерські ускладнення.

\section{СПИСОК ЛІТЕРАТУРИ}

1. Predictive risk factors for persistent postherniotomy pain / E. K. Aasvang, E. Gmaehle, J. B. Hansen [et al.] // Anesthesiology. - 2010. - Vol. 112 (4). - P. 957-969.

2. Guttman R. Appendicitis during pregnancy / R. Guttman, R. D. Goldman, G. Koren // Can. Fam. Physician. - 2004. Vol. 50. - P. 355-357.

3. How time affects the risk of rupture in appendicitis / N. A. Bickell, A. H. Jr Aufses, M. Rojas, C. Bodian // J. Am. Coll. Surg. - 2006. - Vol. 202 (3). - P. 401-406.

4. MR imaging evaluation of acute appendicitis in pregnancy / I. Pedrosa, D. Levine, A. D. Eyvazzadeh [et al.] // Radiology. 2006. - Vol. 238 (3). - P. 891-899.

5. ACR guidance document for safe MR practices: $2007 /$

E. Kanal, A. J. Barkovich, C. Bell [et al.] // Am. J. Roentgenol. -
4. Мініінвазивні технології, які запроваджені в клініці, є методом вибору лікування гострої хірургічної патології органів черевної порожнини, незалежно від триместру.

5. Впровадження мініінвазивних методів дало можливість скоротити кількість перебування вагітних у стаціонарі та використання їх в III триместрі вагітності (8 \% від загальної кількості оперованих).

Перспективи подальших досліджень. Перспективи подальших досліджень передбачають удосконалення методів діагностики та хірургічного лікування гострого апендициту у вагітних жінок, 3 урахуванням результатів передопераційного скринінгу, триместру вагітності та ступеня деструкції черевоподібного відростка з метою профілактики передчасних родорозрішень.

\section{REFERENCES}

1. Aasvang, E.K., Gmaehle, E., Hansen, J.B., Gmaehle, B., Forman, J.L., Schwarz, J., ..., \& Kehlet, H. (2010). Predictive risk factors for persistent postherniotomy pain. Anesthesiology, 112 (4), 957-969. DOI: 10.1097/ALN.0b013e3181d31ff8.

2. Guttman, R., Goldman, R.D., \& Koren, G. (2004). Appendicitis during pregnancy. Can. Fam. Physician, 50, 355-357.

3. Bickell, N.A., Aufses, A.H. Jr, Rojas, M., \& Bodian, C. (2006). How time affects the risk of rupture in appendicitis. J. Am. Coll. Surg., 202 (3), 401-406. DOI: 10.1016/j.jamcollsurg.2005.11.016. 4. Pedrosa, I., Levine, D., Eyvazzadeh, A.D., Siewert, B., Ngo, L., \& Rofsky, N.M. (2006). MR imaging evaluation of acute appendicitis in pregnancy. Radiology., 238 (3), 891-899. DOI: 10.1148/radiol.2383050146.

5. Kanal, E., Barkovich, A.J., Bell, C., Borgstede, J.P., Bradley, W.G. Jr, Froelich, J.W., ..., \& Sass, N. (2007). ACR guidance

2007. - Vol. 88 (6). - P. 1447-1474.

6. ACR Appropriateness criteria: right lower quadrant painsuspected appendicitis / E. M. Garcia, M. A. Camacho, D. R. Karolyi [et al.] // J. Am. Coll. Radiol. - 2018. - Vol. 15 (11S). - P. S373-S387.

7. Donkervoort S. C. Suspicion of acute appendicitis in the third trimester of pregnancy: pros and cons of a laparoscopic procedure / S. C. Donkervoort, D. Boerma // JSLS. - 2011. - Vol. 15 (3). P. 379-383.

8. Gaitán H. G. Laparoscopy for the management of acute lower abdominal pain in women of childbearing age / H. G. Gaitán, L. Reveiz, C. Farquhar // Cochrane Database Syst. Rev. - 2011. Vol. 19 (1). - CD007683. document for safe MR practices: 2007. Am. J. Roentgenol., 188 (6), 1447-1474. DOI: 10.2214/AJR.06.1616.

6. Garcia, E.M., Camacho, M.A., Karolyi, D.R., Kim, D.H., Cash, B.D., Chang, K.J., \& Carucci, L.R. (2018). ACR Appropriateness criteria: right lower quadrant pain-suspected appendicitis. J. Am. Coll. Radiol., 15 (11S), S373-S387. DOI: 10.1016/j. jacr.2018.09.033.

7. Donkervoort, S.C., \& Boerma, D. (2011). Suspicion of acute appendicitis in the third trimester of pregnancy: pros and cons of a laparoscopic procedure. JSLS, 15 (3), 379-383. DOI: 10.4293/1 $08680811 X 13125733356837$.

8. Gaitán, H.G., Reveiz, L., \& Farquhar, C. (2011). Laparoscopy for the management of acute lower abdominal pain in women of childbearing age. Cochrane Database Syst. Rev., 19 (1), CD007683. DOI: 10.1002/14651858.CD007683.pub2. 


\section{M. STETS, N. V. VOYTYUK, V. M. CHERNENKO, V. V. FINOCHKO}

O. Bohomolets National Medical University, Kyiv

\section{ULTRASOUND SCREENING OF ACUTE APPENDICITIS IN PREGNANT WOMEN}

The aim of the work: prevention of premature births by improving diagnostic methods using ultrasound screening and the choice of surgical tactics in pregnant women with acute surgical pathology depending on the results of screening.

Mrterials and Methods. A retrospective review of medical cases and outpatient charts of patients with suspected acute surgical pathology of the abdominal cavity was conducted in the Kyiv City Clinical Hospital No. 1 from 2016 to 2021.

Results and Discussion. All pregnant women underwent the necessary clinical, laboratory and instrumental research methods in accordance with the updated clinical protocols for the provision of surgical care to pregnant women. In some cases, magnetic resonance imaging and computed tomography were performed to detail the spread of the pathological process and, accordingly, the choice of surgical intervention.

Features of the clinical picture of AA are due to anatomical and physiological features of pregnant women. With increasing gestational age, we observed a more pronounced change in the clinical manifestations of AA with a more rapid course of the disease. Indicators of laboratory researches have a certain value in diagnosis of AA in pregnant women. Leukocytosis, neutrophilic shift of the leukocyte formula to the left, lymphocytopenia indicate in favor of appendicitis.

Tocolytic therapy has been used both in preoperative preparation and intraoperatively, which significantly affects the prevention of premature birth and pregnancy complications.

Postoperative complications were not observed in this population.

Detailing the diagnosis in pregnant women with acute surgical pathology using the latest diagnostic methods, gave the opportunity to choose tactics and methodology of surgical treatment. Ultrasound scanning is highly sensitive and specific in $71 \%$ of pregnant women with acute appendicitis.

The introduction of minimally invasive methods has made it possible to reduce the number of pregnant women in the hospital and their use in the third trimester of pregnancy ( $8 \%$ of the total number of operated).

Key words: acute appendicitis; ultrasound screening; pregnant women; laparoscopy; analysis of methods. 